MaPan : Jurnal Matematika dan Pembelajaran

p-ISSN: 2354-6883 ; e-ISSN: 2581-172X

Volume 7, No 2, December 2019 (211-228)

DOI: https://doi.org/10.24252/mapan.2019v7n2a4

\title{
TEORI PIRIE-KIEREN: LAPISAN PEMAHAMAN SISWA SMP BERKEMAMPUAN MATEMATIKA TINGGI DALAM MENYELESAIKAN SOAL BANGUN RUANG
}

\author{
Suindayati1), Dian Septi Nur Afifah'2), Imam Sukwatus Suja'i3) \\ 1,2,3STKIP PGRI Tulungagung \\ 1,2,3Jl. Mayor Sujadi No.7, Manggisan, Plosokandang, Jawa Timur \\ E-mail: suindayati1@gamail.com¹), dian.septi@stkippgritulungagung.ac.id2), \\ imam.sujai@stkippgritulungagung.ac.id ${ }^{3)}$
}

Submitted: 14-08-2019, Revised: 30-10-2019, Accepted: 14-12-2019

\begin{abstract}
Abstrak:
Lapisan pemahaman memiliki peranan penting dalam mengukur tingkat pemahaman siswa dalam belajar dan berpikir, sedangkan tingkat kemampuan matematika memudahkan dalam pemahaman sehingga belajar dan berpikir dilakukan oleh siswa menjadi efektif dan efisien. Tujuan penelitian ini untuk mendeskripsikan lapisan pemahaman siswa SMP yang berkemampuan matematika tinggi dalam menyelesaikan soal bangun ruang berdasarkan teori Pirie Kieren. Jenis penelitian ini adalah deskriptif kualitatif. Penelitian dilaksanakan di kelas VIIIA SMP Negeri 2 Bakung dengan memilih subjek yang berkemampuan matematika tinggi. Teknik pengumpulan data dalam penelitian ini adalah tes dan wawancara. Instrumen yang digunakan dalam penelitian ini adalah tes dan pedoman wawancara. Tes ada dua, yaitu tes kemampuan matematika dan tes lapisan pemahaman. Analisis data dilakukan dengan tiga tahapan, yaitu reduksi data, penyajian data, dan kesimpulan. Hasil penelitian ini menunjukkan bahwa lapisan pemahaman subjek yang berkemampuan tinggi mampu memenuhi semua indikator lapisan pemahaman, yaitu lapisan primitive knowing, image making, image having, property noticing, formalizing, observing, structuring, dan inventising. Selanjutnya diharapkan dalam pembelajaran dapat menggunakan tutor sebaya untuk mengetahui pemahaman siswa dalam pembelajaran di kelas.
\end{abstract}

Kata Kunci: Kemampuan Matematika, Lapisan Pemahaman, Teori Pirie-Kieren

\section{PIRIE-KIRIEN THEORY: UNDERSTANDING LEVELS OF JUNIOR HIGH SCHOOL STUDENTS IN ANSWERING GEOMETRY EXERCISES}

\begin{abstract}
:
Level of understanding has an important role in measuring the students' understanding in learning and thinking, while the level of mathematical difficulties makes easier in understanding so that the students' thinking and learning become effective and efficient. The purpose of this study was to describe the understanding level of junior high school students with high mathematical abilities in solving geometrical problems based on Pirie Kieren's theory. The method was descriptive qualitative research which was conducted in the 8th grade students of SMP Negeri 2 Bakung by selecting subjects with high mathematical ability. The instruments used in this study were tests and interview guidelines. There were two kind of
\end{abstract}


tests, namely the mathematics ability test and the understanding level test. The data was analyzed in three stages, namely data reduction, data presentation, and conclusion. The results of this study indicated that the high levels of understanding of the students were able to fulfill all the indicators of the understanding levels, namely the primitive knowing, image making, image having, property noticing, formalizing, observing, structuring, and inventorying. Furthermore, it was expected that peer tutors to know the students' understanding could be used in classroom learning.

Keywords: Mathematical Ability, Pirie-Kieren Theory, Understanding Levels

How to Cite: Suindayati, Afifah, D. S. N., \& Suja'I, I. S. (2019). Teori PirieKieren: Lapisan pemahaman siswa SMP berkemampuan matematika tinggi dalam menyelesaikan soal bangun ruang. MaPan: Jurnal Matematika dan Pembelajaran, 7(2), 211-228.

\section{PENDAHULUAN}

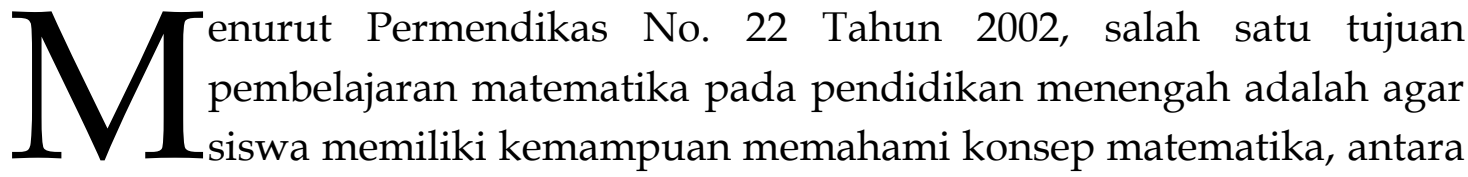
lain menjelaskan keterkaitan antarkonsep, dan mengaplikasikan konsep atau algoritma, secara luwes, akurat, efisien, dan tepat dalam pemecahan masalah. Namun, berdasarkan hasil observasi peneliti di SMP Negeri 2 Bakung, masih banyak siswa yang mengalami kesulitan dalam memahami soal matematika. Hal ini dikarenakan dalam menyelesaikan soal, siswa memiliki cara-cara sendiri yang mungkin berbeda antara siswa satu dengan yang lain karena pemahaman siswa juga berbeda-beda. Hal ini dapat dilihat dari rata-rata nilai ulangan harian matematika salah satu kelas bahwa sebesar $75 \%$ siswa yang tidak lulus KKM.

Penelitian yang dilakukan oleh Afifah (2006) menemukan bahwa tidak semua siswa dapat memahami materi yang dipelajari dengan baik. Hal ini terlihat ketika siswa diminta untuk memecahkan masalah matematika sesuai dengan materi yang telah dipelajari, siswa tampak kebingungan karena tidak mengetahui dari mana dan rumus apa yang digunakan untuk menyelesaikan masalah tersebut. Selain itu, terdapat siswa yang dapat memecahkan masalah tersebut, akan tetapi beberapa siswa tidak mampu memberikan alasan jawaban yang mereka tuliskan, dan ada juga yang dapat menjelaskan alasan jawaban mereka. Bahkan ada juga siswa tidak hanya mengetahui pemecahan suatu masalah matematika, melainkan juga dapat menerapkan pada situasi lain. Penelitian lain yang dilakukan oleh Suhardiman, Tayeb \& Qadri (2017) di 
XI MIA MAN Wajo menyimpulkan bahwa metode scramble berbasis media courselab lebih baik untuk meningkatkan pemahaman konsep dibanding dengan metode scramble berbasis media microsoft power point. Penelitian lain yang dilakukan oleh Mania, Raoda, Rasyid, \& Tayeb (2019) mengemukakan bahwa penerapan model pembelajaran reciprocal teaching efektif terhadap peningkatan motivasi belajar dan pemahaman konsep matematika siswa.

Berdasarkan hal tersebut, sudah seharusnya pembelajaran matematika yang berorientasi pada kemampuan pemahaman perlu diperhatikan. Salah satu teori pemahaman yang terkait dengan hal tersebut adalah teori yang dikemukakan oleh Pirie dan Kieren. Pirie dan Kieren dalam Hakim (2017) memberikan kerangka teoritis berupa delapan level pemahaman yang disebut juga sebagai lapisan pemahaman yaitu primitive knowing, image making, image having, property noticing, formalizing, observing, structuring, dan inventising.

Lapisan pemahaman pertama adalah primitive knowing. Lapisan ini merupakan lapisan usaha awal dalam memahami definisi baru, membawa pengetahuan sebelum ke level pemahaman selanjutnya, lewat aksi yang melibatkan definisi, atau merepresentasikan definisi Pirie dan Kieren dalam Hakim (2017). Lapisan pemahaman kedua disebut image making. Pirie dan Kieren dalam Hakim (2017) mengatakan bahwa seseorang membuat pemahaman dari pengetahuan sebelumnya dan menggunakan dalam cara baru. Lapisan pemahaman ketiga adalah image having. Manu dalam Hakim (2017) mengemukakan bahwa seseorang sudah memiliki gambaran mengenai suatu topik dan membuat gambaran mental mengenai topik tersebut tanpa harus mengerjakan contoh-contoh. Lapisan pemahaman keempat adalah property noticing. Pirie dan Kieren dalam Hakim (2017) mengatakan bahwa seseorang mampu mengombinasikan aspek-aspek dari sebuah topik untuk membentuk sifat yang relevan dan spesifik terhadap topik tersebut. Lapisan pemahaman kelima adalah formalizing. Seseorang membuat abstraksi suatu konsep matematika berdasarkan sifat-sifat yang muncul. Lapisan pemahaman keenam adalah observing. Pirie dan Kieren dalam Hakim (2017) mengatakan bahwa seseorang mengoordinasikan aktivitas formal pada lapisan formalizing sehingga mampu menggunakan pada permasalahan terkait yang dihadapinya. Lapisan pemahaman ketujuh adalah structuring. Pirie dan Kieren dalam Hakim (2017) mengatakan bahwa seseorang mampu mengaitkan hubungan antara teorema yang lain dan mampu membuktikannya berdasarkan argumen yang logis. Lapisan pemahaman kedelapan adalah inventising. Pirie dan Kieren dalam Hakim (2017) mengatakan bahwa seseorang memiliki sebuah 
pemahaman terstruktur komplit dan menciptakan pertanyaan-pertanyaan baru yang dapat tumbuh menjadi sebuah konsep yang baru.

Salah satu faktor yang mempengaruhi pemahaman siswa dalam menyelesaikan soal matematika adalah kemampuan matematika. Kemampuan merupakan kesanggupan dan kecakapan dalam menyelesaikan suatu hal dengan usaha sendiri (Astuti, 2015). Sudijono (2010) mengelompokkan tingkat kemampuan matematika menjadi 3 tingkatan yaitu tinggi, sedang, dan rendah, sehingga akan lebih mudah mengetahui bagaimana lapisan pemahaman yang dicapai siswa dalam menyelesaikan masalah dilihat dari kemampuan matematika.

Penelitian tentang pemahaman sudah banyak dilakukan sebelumnya. Namun, masih sedikit yang meneliti tentang lapisan pemahaman berdasarkan teori Pirie-Kieren. Seperti penelitian sebelumnya yang dilakukan oleh Hakim (2017) yang meneliti tentang analisis pemahaman mahasiswa PPS UNM berpandu teori Pirie-Kieren dalam menyelesaikan masalah pembuktian pada teori grup ditinjau dari gaya kognitif dan adversity quotient. Hasil penelitiannya menjelaskan bahwa setiap jenis subjek dengan gaya kognitif memiliki level pemahaman yang berbeda-beda. Penelitian lain yang dilakukan oleh Pratama (2017) yang meneliti tentang perkembangan pemahaman matematis siswa sekolah dasar kelas $\mathrm{V}$ berdasarkan teori Pirie-Kieren pada topik pecahan menyimpulkan bahwa terdapat kesamaan alur perkembangan pemahaman siswa sekolah dasar kelas $\mathrm{V}$ dalam menyelesaikan masalah pecahan.

Berdasarkan beberapa pendapat di atas, maka yang dimaksud pemahaman dalam penelitian ini adalah kemampuan mengetahui pengetahuan sederhana, mampu membuat gambaran mengenai pengetahuan dari pengetahuan tersebut, memiliki gambaran mengenai pengetahuan tersebut, memperhatikan sifat-sifat dari pengetahuan tersebut, memformalkan pengetahuan yang berkaitan, mengamati pengetahuan yang sudah didapatkan, penataaan pengetahuan yang sudah didapatkan, dan yang terakhir mampu melakukan penemuan pengetahuan yang berkaitan. Dalam penelitian ini lapisan pemahaman yang digunakan menurut teori Pirie Kieren yaitu primitive knowing, image making, image having, property noticing, formalizing, observing, structuring, dan inventising. Kemampuan matematika yang dimaksud adalah kemampuan yang dibutuhkan untuk melakukan berbagai aktifitas mental, berpikir, dan memecahkan masalah dalam menyelesaikan soal-soal matematika. Kategori tingkatan kemampuan matematika yang digunakan dalam penelitian ini yaitu kategori tingkat 
kemampuan tinggi. Dengan mengetahui pemahaman siswa yang memiliki kemampuan tinggi, mereka dapat menjadi tutor sebaya untuk siswa yang memiliki kemampuan sedang dan rendah sehingga tujuan pembelajaran tercapai. Oleh karena itu lapisan pemahaman memiliki peranan penting dalam mengukur tingkat pemahaman siswa dalam belajar dan berpikir, dan tingkat kemampuan matematika memudahkan dalam pemahaman sehingga belajar dan berpikir yang dilakukan oleh siswa menjadi lebih efektif dan efisien.

Untuk itu, peneliti tertarik untuk mengangkat masalah ini ke dalam penelitian yang berjudul “Teori Pirie-Kieren: Lapisan Pemahaman Siswa SMP Berkemampuan Matematika Tinggi dalam Menyelesaikan Soal Bangun Ruang". Dengan mengetahui lapisan pemahaman siswa kemampuan tinggi, maka guru dapat mengoptimalkan pembelajaran di kelas dengan menggunakan tutor sebaya bagi siswa lain. Hal ini sejalan dengan pendapat Hardiyanti, Lefrida, \& Amri (2015) yang menyatakan tutor sebaya baik dilaksanakan, karena siswa dapat berdiskusi satu sama lain dan dapat membantu temannya yang mengalami kesulitan dalam memahami pelajaran atau siswa yang berkemampuan tinggi dapat membantu siswa yang berkemampuan rendah karena bisa bertanya kepada tutornya masing-masing. Penelitian ini diharapkan dapat memberikan informasi dalam pendidikan matematika yang berkaitan dengan lapisan pemahaman siswa SMP berdasarkan teori Pirie-Kieren yang ditinjau dari kemampuan matematika.

\section{METODE PENELITIAN}

Jenis penelitian yang dilakukan oleh peneliti adalah penelitian deskriptif dengan pendekatan kualitatif studi kasus yang bertujuan mendeskripsikan lapisan pemahaman siswa SMP dalam menyelesaikan soal bangun ruang berdasarkan teori Pirie-Kieren ditinjau dari kemampuan matematika. Prosedur penelitian meliputi kegiatan awal, kegiatan pelaksanaan dan kegiatan akhir. Penelitian ini dilakukan di kelas VIIIA SMP Negeri 2 Bakung. Teknik pemilihan subjek adalah melalui tes kemampuan matematika. Satu kelas diberikan tes kemampuan matematika, selanjutnya hasilnya dianalisis dan dikelompokkan menjadi tiga yaitu siswa yang memiliki kemampuan tinggi, sedang, dan rendah. Dalam penelitian ini, peneliti memilih satu siswa yang memiliki kemampuan tinggi dan memiliki komunikasi yang baik dan dikodekan dengan KT. Data dikumpulkan berdasarkan tes dan wawancara. Instrumen utama dalam penelitian ini adalah peneliti sendiri dan instrumen pendukung adalah instrumen tes kemampuan 
matematika dan instrumen tes sebelum dilakukan tes di lapangan. Soal tes divalidasi oleh satu dosen dan satu guru di sekolah tempat dilaksanakan penelitian. Hasil validasi menunjukkan bahwa soal tes kemampuan matematika, tes pemahaman, dan pedoman wawancara dapat digunakan dengan beberapa revisi. Lapisan pemahaman dianalisis berdasarkan teori Pirie-Kieren. Selanjutnya, untuk mengecek keabsahan data digunakan triangulasi metode yaitu dengan membandingkan hasil tes dengan hasil wawancara. Setelah diperoleh data yang valid, maka dilakukan analisis. Analisis data meliputi reduksi data, penyajian data, dan penarikan kesimpulan. Analisis data dilakukan secara kualitatif untuk menentukan level pemahaman matematika siswa. Berikut indikator lapisan pemahaman yang digunakan dalam penelitian ini.

Tabel 1. Indikator Lapisan Pemahaman berdasarkan Teori Pemahaman PirieKieren

\begin{tabular}{|c|c|c|}
\hline No. & $\begin{array}{c}\text { Lapisan } \\
\text { Pemahaman }\end{array}$ & Indikator \\
\hline 1 & Primitive knowing & $\begin{array}{l}\text { a. Menyebutkan semua definisi dari istilah- } \\
\text { istilah yang ditemukan dalam masalah. } \\
\text { b. Menjelaskan semua definisi dari istilah- } \\
\text { istilah yang ditemukan dalam masalah. } \\
\text { c. Memberikan contoh yang berkaitan } \\
\text { dengan istilah-istilah dalam masalah. }\end{array}$ \\
\hline 2 & Image making & $\begin{array}{l}\text { a. Mendapatkan ide atau gambaran yang } \\
\text { akan digunakan dalam menyelesaikan } \\
\text { masalah } \\
\text { b. Mampu menjelaskan ide atau gambaran } \\
\text { yang akan digunakan dalam } \\
\text { menyelesaikan masalah } \\
\text { menggunakan contoh. }\end{array}$ \\
\hline 3 & Image having & $\begin{array}{l}\text { a. Mendapatkan ide atau gambaran yang } \\
\text { akan digunakan dalam menyelesaikan } \\
\text { masalah dan } \\
\text { b. Mampu menjelaskan ide atau gambaran } \\
\text { penyelesaian tersebut tanpa menggunakan } \\
\text { contoh. }\end{array}$ \\
\hline 4 & Property noticing & $\begin{array}{l}\text { a. Menyadari adanya hubungan antar } \\
\text { definisi-definisi yang dipahami pada tahap } \\
\text { primitive knowing. } \\
\text { b. Memverifikasi hubungan antar definisi- }\end{array}$ \\
\hline
\end{tabular}




\begin{tabular}{|c|c|c|c|}
\hline & & & definisi tersebut. \\
\hline 5 & Formalising & a. & $\begin{array}{l}\text { Menemukan konsep } \text { sendiri dan } \\
\text { menggunakan konsep yang ditemukan } \\
\text { untuk menyelesaikan masalah yang } \\
\text { diberikan. }\end{array}$ \\
\hline 6 & Organising & a. & $\begin{array}{l}\text { Menemukan pola terstruktur dari konsep } \\
\text { untuk menyelesaikan masalah yang } \\
\text { diberikan. } \\
\text { Membuat suatu pernyataan formal dari } \\
\text { pola yang ditemukan untuk menyelesaikan } \\
\text { maslah yang diberikan. }\end{array}$ \\
\hline 7 & Structuring & a. & $\begin{array}{l}\text { Mengaitkan hubungan antara rumus yang } \\
\text { satu dengan rumus yang lain dan mampu } \\
\text { membuktikan berdasarkan argumen logis. }\end{array}$ \\
\hline 8 & Investising & & $\begin{array}{l}\text { Memiliki sebuah pemahaman terstruktur } \\
\text { komplit dan menciptakan pertanyaan- } \\
\text { pertanyaan baru yang dapat tumbuh } \\
\text { menjadi sebuah konsep baru. }\end{array}$ \\
\hline
\end{tabular}

\section{HASIL PENELITIAN DAN PEMBAHASAN}

Lapisan pemahaman siswa yang berkemampuan matematika tinggi (KT) sebagai berikut.

a. Soal nomor satu lapisan pemahaman primitif knowing.

1. Sebutkan contoh benda yang ada di sekitar anda yang berbentuk kubus!

2. Gambarkan sebuah kubus!

3. Sebutkan sifat-sifat dari kubus tersebut!

Hasil tes pemahaman dan wawancara subjek KT sebagai berikut.

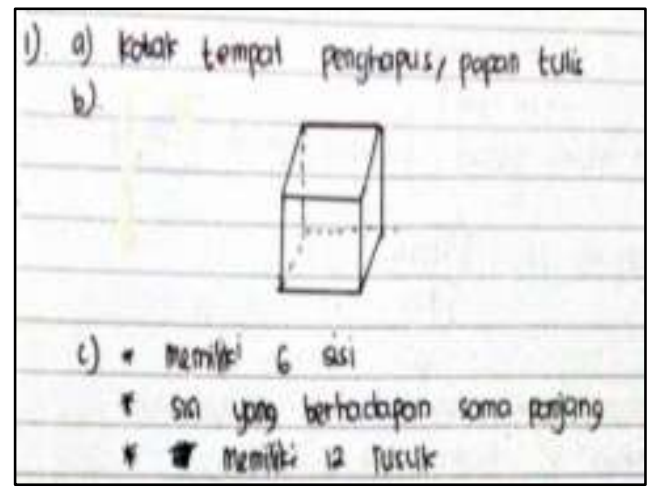

Gambar 1. Jawaban Nomor 1 
Subjek KT menjawab dengan benar untuk soal nomor 1 baik 1a, 1b, dan 1c. Selain itu, subjek juga menggunakan pemahaman bangun ruang pada kubus dalam menyelesaikan soal nomor 1, untuk soal nomor 1a dengan menyebutkan contoh benda yang ada di sekitar subjek yang berbentuk kubus yaitu kotak tempat penghapus papan tulis, untuk soal nomor 1b subjek KT sudah bisa menggambarkan sebuah kubus, sedangkan untuk soal nomor 1c subjek KT menyebutkan sifat-sifat kubus yaitu memiliki 6 sisi, sisi yang berhadapan sama panjang, dan memiliki 12 rusuk. Akan tetapi belum diketahui lapisan pemahaman yang dimiliki subjek KT. Untuk itu, dilakukan wawancara yang hasilnya sebagai berikut:

Peneliti : : : apa yang anda pikirkan setelah membaca soal 1a, 1b, dan 1c ?

KT :"untuk 1a disuruh menyebutkan contoh benda disekitar yang seperti kubus, 1b menggambarkan kubus, dan 1c menyebutkan sifat-sifat kubus"

Peneliti : : :lalu apa jawaban anda?

KT : " $1 \mathrm{a}$ kotak tempat penghapus dan papan tulis, $1 \mathrm{~b}$ ini gambarnya, dan 1c sifat-sifat kubus adalah memiliki 6 sisi, sisi yang behadapan sama panjang, dan memiliki 12 rusuk"

Berdasarkan petikan wawancara di atas, tampak bahwa langkah pertama peneliti menanyakan pada subjek apa yang dipikirkan pada soal nomor 1 , dan subjek menjawab untuk $1 \mathrm{a}$, selanjutnya peneliti menanyakan $1 \mathrm{~b}$, dan 1c, dan subjek menjawab dengan benar.

Berdasarkan deskripsi hasil tes lapisan pemahaman dan hasil wawancara, subjek KT dapat memberikan contoh kubus yaitu dengan menyebutkan tempat penghapus dan papan tulis, menggambarkan bentuk kubus, dan menyebutkan sifat-sifat kubus yaitu memiliki 6 sisi, sisi yang berhadapan sama panjang, dan memiliki 12 rusuk. Dengan demikian, berdasarkan indikator yang digunakan dalam penelitian ini, maka subjek KT memenuhi lapisan pemahaman image making.

b. Soal nomor 2 lapisan pemahaman image making

Berapa banyak kubus satuan penyusun kubus di bawah ini ?

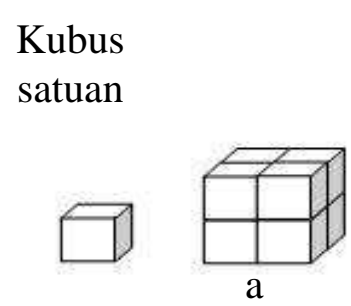

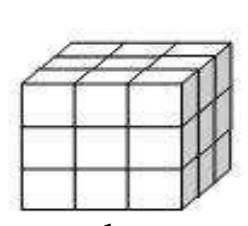

b

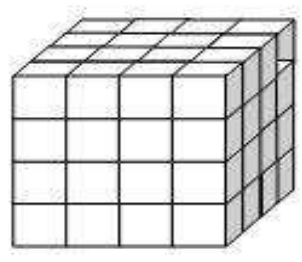

c 
Hasil jawaban tes lapisan pemahaman dan hasil wawancara subjek KT sebagai berikut.

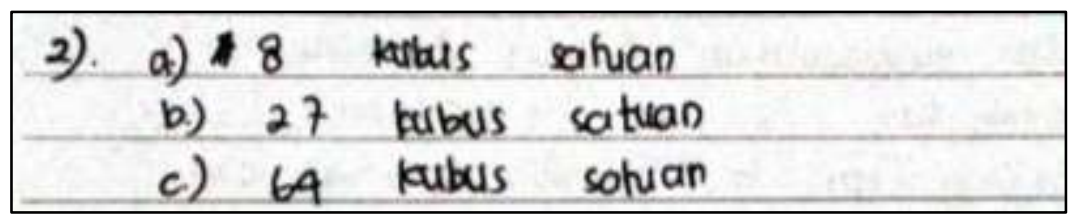

Gambar 2. Jawaban Nomor 2

Pada gambar 2, subjek KT menjawab dengan benar untuk soal nomor 2 baik 2a, 2b, dan 2c yang diberikan. Selain itu, subjek juga menggunakan pemahaman penyusun kubus dari kubus satuan dalam menyelesaikan soal nomor 2. Di dalam jawaban tersebut untuk kubus a subjek KT menjawab ada 8 kubus satuan penyusun kubus a, kemudian untuk kubus b subjek KT menjawab ada 27 kubus satuan penyusun kubus b, sedangkan untuk kubus c subjek KT menjawab ada 64 kubus satuan penyusun kubus c. Akan tetapi belum diketahui bagaimana lapisan pemahaman yang dimiliki subjek KT. Untuk itu dilakukan wawancara yang hasilnya sebagai berikut:

Peneliti : : untuk soal nomor 2 yang ditanyakan apa?"

KT : : banyaknya kubus satuan penyusun kubus a, b, c"

Peneliti :"iya, lalu jawaban anda kubus satuan penyusun kubus a, b, c berapa?"

KT :"a 8 kubus satuan, b 27 kubus satuan, dan c 64 kubus satuan”

Berdasarkan petikan wawancara di atas, tampak bahwa langkah pertama peneliti menanyakan pada subjek apa yang ditanyakan pada soal nomor 2 dan jawabannya, dan subjek menjawab mencari banyaknya kubus satuan penyusun kubus a, b, c yaitu penyusun kubus a 8 satuan, kubus b 27 satuan, dan kubus c 24 satuan.

Berdasarkan deskripsi hasil tes lapisan pemahaman dan hasil wawancara, subjek KT dapat memberikan jawaban yaitu dengan menjawab ada 8 kubus satuan penyusun kubus a, kubus b ada 27 kubus satuan penyusun kubus b, dan untuk kubus c ada 64 kubus satuan penyusun kubus c. Dengan demikian berdasarkan indikator yang digunakan dalam penelitian ini, maka subjek KT memenuhi lapisan pemahaman image making.

c. Soal nomor tiga lapisan pemahaman image having

Tentukan volume kubus yang memiliki panjang sisi 2 satuan, 3 satuan dan 6 satuan! 
Hasil tes lapisan pemahaman dan wawancara subjek KT adalah sebagai berikut.

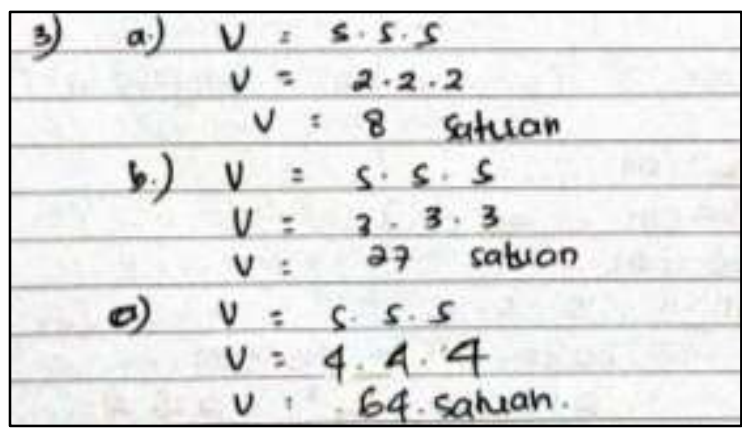

Gambar 3. Jawaban Nomor 3

Subjek KT menjawab dengan benar untuk soal nomor 3 yang diberikan. Selain itu, subjek juga menggunakan konsep volume kubus dalam menyelesaikan soal nomor 3 dengan menggunakan rumus $V=s \times s \times s$. Subjek KT menjawab untuk volume kubus a $V=2 \times 2 \times 2$ adalah 6 satuan. Kemudian untuk volume kubus b subjek KT menjawab $V=3 \times 3 \times 3$ adalah 27 satuan. Selanjutnya untuk volume kubus c subjek KT menjawab $V=4 \times$ $4 \times 4$ adalah 64 satuan. Akan tetapi belum diketahui bagaimana lapisan pemahaman yang dimiliki subjek KT. Untuk itu dilakukan wawancara yang hasilnya sebagai berikut:

Peneliti : : :lalu untuk soal nomor 3 yang ditanyakan apa?"

KT :"volume kubus a, kubus b, kubus c, yaitu 6 satuan, 27 satuan, 64 satuan"

Berdasarkan petikan wawancara di atas, tampak bahwa peneliti menanyakan apa yang ditanyakan soal nomor 3. Subjek menjawab menentukan volume kubus a, b, c. Kemudian subjek menjawab dengan benar.

Berdasarkan deskripsi hasil jawaban tes lapisan pemahaman dan hasil wawancara, subjek KT dapat menjawab volume kubus a, kubus b, dan kubus c yaitu untuk volume kubus a adalah 8 satuan, volume kubus b adalah 27 satuan, dan untuk volume kubus c adalah 64 satuan. Dengan demikian, berdasarkan indikator yang digunakan dalam penelitian ini, maka subjek KT memenuhi lapisan pemahaman image having.

d. Soal nomor empat lapisan pemahaman property noticing

Jelaskan bagaiman cara menghitung volume kubus?

Hasil tes lapisan pemahaman dan hasil wawancara subjek KT: 


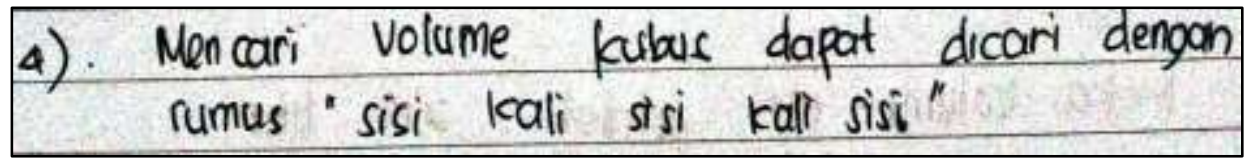

Gambar 4. Jawaban Nomor 4

Pada gambar 4, subjek KT menjawab dengan benar untuk soal nomor 4 yang diberikan. Selain itu subjek juga menggunakan konsep rumus volume kubus menyelesaikan soal nomor 2 dengan menuliskan mencari volume kubus dengan rumus sisi kali sisi kali sisi. Akan tetapi belum diketahui bagaimana lapisan pemahaman yang dimiliki subjek KT. Untuk itu dilakukan wawancara yang hasilnya sebagi berikut:

Peneliti : : :lalu, apa yang ditanyakan soal nomor 4, dan apa jawabannya?"

KT :"cara menghitung volume kubus, yaitu sisi kali sisi kali sisi"

Berdasarkan petikan wawancara di atas, tampak bahwa peneliti menanyakan apa yang ditanyakan pada soal nomor 4. Subjek menjawab cara menghitung volume kubus yaitu sisi kali sisi kali sisi. Berdasarkan deskripsi hasil lapisan pemahaman dan hasil wawancara, subjek KT dapat menjawab cara menghitung volume kubus yaitu sisi kali sisi kali sisi. Dengan demikian berdasarkan indikator yang digunakan dalam penelitian ini, maka subjek KT memenuhi lapisan pemahaman property noticing.

e. Soal nomor lima lapisan pemahaman formalizing

Tuliskan rumus untuk menghitung volume kubus dan berikan penjelasan bagaimana Anda mendapatkan rumus tersebut!

Hasil tes lapisan pemahaman dan hasil wawancara subjek KT:

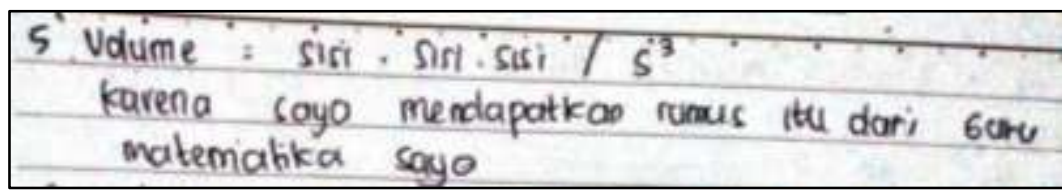

Gambar 5. Jawaban Nomor 5

Pada gambar 5, subjek KT menjawab dengan benar soal nomor 5 yang diberikan. Selain itu subjek juga menggunakan konsep rumus volume kubus yaitu sisi kali sisi kali sisi atau $s^{3}$ dan memberikan alasan penggunaan rumus. Akan tetapi, belum diketahui bagaimana lapisan pemahaman yang dimiliki subjek KT. Untuk itu, dilakukan wawancara yang hasilnya sebagai berikut: 
Peneliti : : : : lalu soal no. 5 apa yang ditanyakan dan jawabannya?"

KT :"rumus volume kubus sisi kali sisi kali sisi atau $\mathrm{s}^{3}$,alasannya saya mendapatkan rumus itu dari guru matematika saya

Berdasarkan petikan wawancara di atas, tampak bahwa peneliti menanyakan soal nomor 5 dan alasan mendapatkan rumus, lalu subjek KT menjawab sisi kali sisi kali sisi atau $s^{3}$, dengan alasan siswa mendapatkan rumus volume kubus dari guru matematika.

Bedasarkan deskripsi hasil tes lapisan pemahaman dan hasil wawancara subjek KT dapat menuliskan rumus volume kubus yaitu volume $=\operatorname{sisi} \times \operatorname{sisi} \times s i s i / \mathrm{s}^{3}$ dan memberikan alasan mendapatkan rumus yaitu subjek mendapatkan rumus dari guru matematika. Dengan demikian, berdasarkan indikator yang digunakan dalam penelitian ini, maka subjek KT memenuhi lapisan pemahaman formalizing.

f. Soal nomor 6 lapisan pemahaman observing

Diketahui kubus dengan panjang sisinya $12 \mathrm{~cm}$, hitunglah volumenya!

Hasil tes lapisan pemahaman dan hasil wawancara subjek KT.

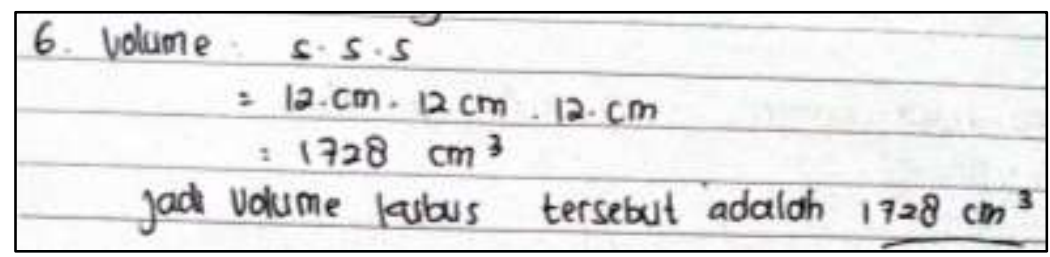

Gambar 6. Jawaban Soal Nomor 6

Subjek KT menjawab dengan benar untuk soal nomor 6. Selain itu, subjek juga menggunakan konsep rumus volume kubus untuk menyelesaikan soal nomor 6 mencari volume kubus yang diketahui panjang sisinya $12 \mathrm{~cm}$, kemudian subjek menuliskan jawabannya $V=s \times s \times s$, yaitu $12 \mathrm{~cm} \times 12 \mathrm{~cm} \times$ $12 \mathrm{~cm}=1728 \mathrm{~cm}^{3}$ dan subjek KT menuliskan kesimpulan jawabannya yaitu "jadi volume kubus tersebut adalah $1728 \mathrm{~cm}^{3}$ ". Akan tetapi belum diketahui bagaimana lapisan pemahaman yang dimiliki subjek KT. Untuk itu, dilakukan wawancara yang hasilnya sebagai berikut:

Peneliti : : lalu soal no.6 ini yang ditanyakan apanya?"

KT : : mencari volume kubus yang diketahui panjang sisinya"

Peneliti : : : lalu apa jawaban anda?"

KT :"volume kubus yaitu V $=\mathrm{s} \times \mathrm{s} \times \mathrm{s}$ yaitu $12 \mathrm{~cm} \times 12 \mathrm{~cm} \times 12 \mathrm{~cm}=$ $1728 \mathrm{~cm}^{3}$, jadi volume kubus tersebut adalah $1728 \mathrm{~cm}^{3 \prime \prime}$ 
Berdasarkan petikan wawancara di atas, tampak peneliti menanyakan terlebih dahulu apa yang ditanyakan dalam soal nomor 6. Kemudian subjek menjawab yang ditanyakan adalah volume kubus yang diketahui panjang sisinya. Selain itu, subjek KT mampu menjelaskan dengan benar langkahlangkahnya dalam menyelesaikan soal tersebut sampai menemukan jawabannya.

Berdasarkan deskripsi hasil jawaban tes lapisan pemahaman dan hasil wawancara, subjek KT dapat menjawab volume kubus dengan panjang sisi yang diketahui yaitu $V=s \times s \times s$ yaitu $12 \mathrm{~cm} \times 12 \mathrm{~cm} \times 12 \mathrm{~cm}=1728 \mathrm{~cm}^{3}$. Dengan demikian, berdasarkan indikator yang digunakan dalam penelitian ini, maka subjek KT memenuhi lapisan pemahaman observing.

g. Soal nomor tujuh lapisan pemahaman structuring

Yoga mempunyai sebuah akuarium berbentuk kubus yang diisi ikan hias dan air penuh dengan volume akuarium tersebut adalah $729 \mathrm{~cm}^{3}$. Berapakah panjang sisi akuarium tersebut? Jelaskan!

Hasil tes lapisan pemahaman dan hasil wawancara:

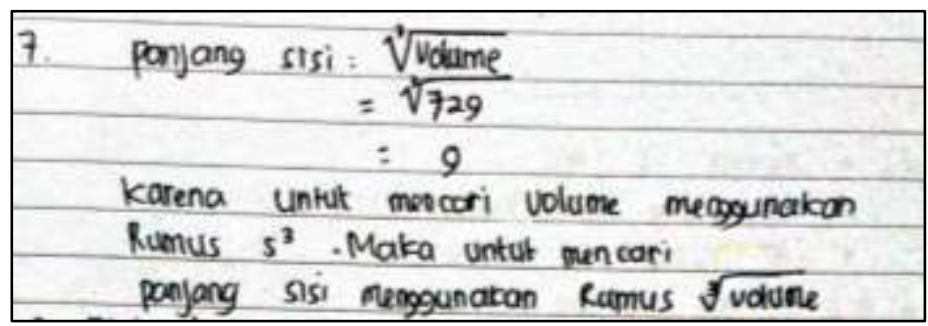

Gambar 7. Jawaban Nomor 7

Pada gambar 7, subjek KT menjawab dengan benar untuk soal nomor 7 yang diberikan. Selain itu subjek juga menggunakan rumus volume kubus untuk menyelesaikan soal nomor 7 dengan mengakar tiga volume untuk mengetahui panjang sisi kubus yaitu panjang sisi $=\sqrt[3]{\text { volume }}=\sqrt[3]{729}=9 \mathrm{~cm}$, serta menuliskan alasan menggunakan rumus itu yaitu karena untuk mencari volume menggunakan rumus $s^{3}$, maka untuk mencari panjang sisi menggunakan rumus $\sqrt[3]{\text { volume }}$. Akan tetapi, belum diketahui bagaimana lapisan pemahaman yang dimiliki subjek KT. Untuk itu, dilakukan wawancara yang hasilnya sebagai berikut.

Peneliti : : :lalu soal no.7 yang diketahui apa dan yang ditanyakan apa?" KT :"diketahui Volume kubus disuruh mencari panjang sisi kubus" 
Peneliti : : : lalu apa jawaban anda, dan alasannya?"

KT :"panjang sisi $=\sqrt[3]{729}=9 \mathrm{cmkarena}$ untuk mencari volume kubus menggunakan rumus $\mathrm{s}^{3}$ maka untuk mencari panjang sisi menggunakan rumus $\sqrt[3]{\text { volume }}$

Berdasarkan petikan wawancara di atas, peneliti terlebih dahulu menanyakan apa yang diketahui pada soal nomor 7, dan subjek menjawab volume kubus yaitu $729 \mathrm{~cm}^{3}$. Kemudian peneliti menanyakan apa yang ditanyakan pada soal tes, dan subjek menjawab panjang sisi kubus. Setelah itu, peneliti meminta subjek menyebutkan panjang sisi kubus tersebut, dan subjek menjawab panjang $s i s i=\sqrt[3]{729}=9 \mathrm{~cm}$, lalu peneliti menanyakan alasan mengapa menggunakan rumus tersebut, dan subjek menjawab untuk mencari volume menggunakan rumus $s^{3}$, maka untuk mencari panjang sisi menggunakan rumus $\sqrt[3]{\text { volume. }}$

Berdasarkan deskripsi hasil tes lapisan pemahaman dan hasil wawancara subjek KT dapat mencari panjang sisi akuarium yang diketahui volumenya yaitu panjang sisi $=\sqrt[3]{\text { volume }}=\sqrt[3]{729}=9 \mathrm{~cm}$. Dengan demikian, berdasarkan indikator yang digunakan dalam penelitian ini, maka subjek KT memenuhi lapisan pemahaman structuring.

h. Soal nomor delapan lapisan pemahaman investising

Suatu bak mandi berbentuk kubus. Bagian luar bak mandi panjang sisinya $1 \mathrm{~m}$, dan bagian tepinya adalah $10 \mathrm{~cm}$. Tentukan volume air bak mandi tersebut!

Hasil tes lapisan pemahaman dan hasil wawancara:

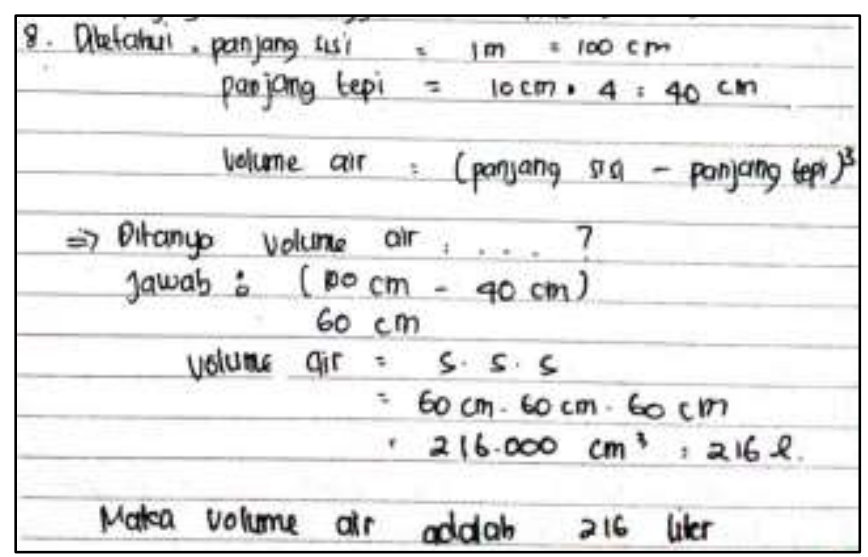

Gambar 8. Jawaban Nomor 8

Subjek KT menjawab dengan benar untuk soal nomor 8 serta menuliskan yang diketahui dan ditanyakan pada soal. Selain itu, subjek juga 
menggunakan konsep rumus volume kubus untuk mencari volume air bak mandi pada soal nomor 8. Subjek menuliskan langkah pertama yaitu menuliskan panjang sisi $1 \mathrm{~m}$ dijadikan $100 \mathrm{~cm}$, untuk panjang tepi $10 \mathrm{~cm}$ dikali 4 tepi $=40 \mathrm{~cm}$, kemudian menuliskan yang ditanyakan pada soal yaitu volume air dan subjek menjawab panjang sisi tepi dalam sama dengan panjang sisipajang tepi yaitu $100 \mathrm{~cm}-40 \mathrm{~cm}=60 \mathrm{~cm}$. Jadi, volume air adalah sisi $\times$ sisi $\times$ sisi $=60 \mathrm{~cm} \times 60 \mathrm{~cm} \times 60 \mathrm{~cm}=216.000 \mathrm{~cm}^{3}$. Volume air dirubah menjadi liter yaitu $216.000 \mathrm{~cm}^{3}$ menjadi 216 liter, jadi volume air dalah 216 liter. Akan tetapi, belum diketahui lapisan pemahaman yang dimiliki subjek KT. Untuk itu, dilakukan wawancara yang hasilnya sebagai berikut:

Peneliti : : :lalu pada soal nomor 8 apa yang diketahui dan ditanyakan?"

KT :"diketahui panjang sisi luar dan panjang tepi dan yang ditanyakan volume air"

Peneliti : : :lalu bagaimana and menjawannya?"

KT :"yang pertama mengubah panjang sisi $1 \mathrm{~m}$ menjadi $100 \mathrm{~cm}$, panjang tepi $10 \mathrm{~cm}$ dikali 4 tepi menjadi $40 \mathrm{~cm}$. kemudian mencari panjang sisi dalam yaitu panjang sisi luar-panjang tepi yaitu $100 \mathrm{~cm}-40 \mathrm{~cm}=60 \mathrm{~cm}$, maka volume air adalah $\mathrm{s} \times \mathrm{s} \times \mathrm{s}=$ $60 \mathrm{~cm} \times 60 \mathrm{~cm} \times 60 \mathrm{~cm}=216.000 \mathrm{~cm}^{3}$. karena satuan volume air itu liter maka $216.000 \mathrm{~cm}^{3}$ dirubah menjadi 216 liter, jadi volume air adalah 216 liter"

Berdasarkan petikan wawancara di atas, tampak peneliti menanyakan terlebih dahulu apa yang diketahui dan ditanyakan pada soal tes. Subjek menjawab yang diketahui panjang sisi dan panjang tepi dan yang ditanyakan volume air. Selain itu, subjek KT mampu menjelaskan dengan benar langkahlangkahnya dalam menyelesaikan soal tersebut sampai menemukan jawaban.

Berdasarkan deskripsi hasil tes lapisan pemahaman dan hasil wawancara subjek KT dapat mencari volume air dengan cara mengubah panjang sisi $1 \mathrm{~m}$ menjadi $100 \mathrm{~cm}$, panjang tepi $10 \mathrm{~cm}$ dikali 4 tepi menjadi 40 $\mathrm{cm}$, kemudian mencari panjang sisi dalam yaitu panjang sisi luar-panjang tepi yaitu $100 \mathrm{~cm}-40 \mathrm{~cm}=60 \mathrm{~cm}$, maka volume air adalah $\mathrm{s} \times \mathrm{s} \times \mathrm{s}=60 \mathrm{~cm} \times$ $60 \mathrm{~cm} \times 60 \mathrm{~cm}=216.000 \mathrm{~cm}^{3}$. Karena satuan volume air itu liter maka 216.000 $\mathrm{cm}^{3}$ dirubah menjadi 216 liter, jadi volume air adalah 216 liter. Dengan demikian berdasarkan indikator yang digunakan dalam penelitian ini, maka subjek KT memenuhi lapisan pemahaman investising.

Subjek yang memiliki kemampuan matematika tinggi, sudah mampu memenuhi semua indikator lapisan pemahaman. Pada lapisan pemahaman primitif knowing subjek sudah mampu menyebutkan dan menjelaskan definisi 
dari istilah-istilah yang ditemukan dalam masalah, dan subjek mampu memberikan contoh yang berkaitan dengan istilah-istilah dalam masalah. Hal ini sesuai dengan pendapat Safitri, Mulyani, \& Ratu (2018) bahwa siswa sudah mempunyai pemahaman awal yang berkaitan dengan topik dan mampu menjelaskan pengetahuan sederhana yang dimiliki.

Pada lapisan pemahaman image making subjek sudah mampu mendapatkan dan menjelaskan ide atau gambaran yang akan digunakan dalam menyelesaikan masalah dengan menggunakan contoh. Hal ini sesuai pendapat Safitri, Mulyani, \& Ratu (2018) bahwa siswa mampu membuat gambaran penyelesaian dari pemahaman sebelumnya, dapat mengembangkan ide-ide tertentu serta membuat gambaran suatu konsep melalui contoh-contoh soal tentang pertidaksamaan logaritma. Pada lapisan pemahaman image having, subjek sudah mampu mendapatkan ide atau gambaran yang digunakan dalam menyelesaikan masalah tanpa menggunakan contoh. Hal ini sesuai dengan pendapat Safitri, Mulyani, \& Ratu (2018) bahwa siswa sudah memiliki gambaran abstrak terkait langkah-langkah penyelesaian soal dengan lengkap tanpa mengerjakan contoh-contoh soal sebelumnya.

Pada lapisan pemahaman property noticing, subjek sudah mampu menyadari adanya hubungan antar definisi-definisi yang dipahami pada tahap primitif knowing serta memverifikasi hubungan tersebut. Hal ini sesuai pendapat Komariyah, Septi, Afifah, \& Resbiantoro (2018) bahwa mengklarifikasi menurut sifat tertentu dengan tepat. Pada lapisan pemahaman formalizing, subjek sudah mampu menentukan konsep sendiri dan menggunakan konsep yang ditemukan untuk menyelesaikan masalah yang diberikan tersebut. Hal ini sesuai pendapat Komariyah, Septi, Afifah, \& Resbiantoro (2018) bahwa mampu menerapkan konsep secara algoritma serta menyajikan dalam bentuk representasi yang benar.

Pada lapisan pemahaman observing, subjek sudah mampu menemukan pola terstruktur dari konsep dan membuat suatu pernyataan formal untuk menyelesaikan masalah yang diberikan tersebut. Hal ini sesuai pendapat Komariyah, Septi, Afifah, \& Resbiantoro (2018) bahwa siswa mampu menerapkan konsep secara algoritma serta menyajikannya ke dalam bentuk representasi yang benar. Pada lapisan pemahaman structuring, subjek sudah mampu mengaitkan hubungan antara rumus yang satu dengan rumus yang lain dan mampu berdasarkan argument logis. Hal ini sesuai pendapat Widyawati, Astuti, \& Ijudin (2018) bahwa siswa sudah mampu mencapai tahap indikator transformasi. Pada lapisan pemahaman investiving, subjek 
sudah mampu memiliki sebuah pemahaman tersruktur komplit dan menciptakan pertanyaan-pertanyaan baru yang dapat tumbuh menjadi sebuah konsep baru. Hal ini sesuai dengan penelitian Aisah (2017) yang menyatakan bahwa siswa yang memiliki kemampuan maematika tinggi dalam menyelesaikan soal logaritma dapat mencapai kedelapan lapisan pemahaman.

\section{SIMPULAN}

Lapisan pemahaman siswa SMP yang berkemampuan matematika tinggi dalam menyelesaikan soal bangun ruang berdasarkan teori Pirie-Kieren, yaitu lapisan primitive knowing, image making, image having, property noticing, formalizing, observing, structuring, dan inventising. Subjek dalam penelitian ini sudah memenuhi semua indikator lapisan pemahaman, dalam hal ini subjek sudah mampu memiliki pengetahuan dasar dalam menyelesaikan soal, membuat gambaran dari pengetahuan dasar tersebut, memiliki gambaran dari pengetahuan tersebut, memperhatikan sifat-sifat dari gambaran tersebut lalu memformalkan pengetahuan tersebut, subjek mampu melakukan pengamatan dari penyelesaian soal tersebut mulai dari penstrukturan dari pengetahuan tersebut, dan subjek sudah mampu menciptakan suatu pemahaman sendiri. Untuk penelitian selanjutnya, peneliti menyarankan agar tidak hanya ditinjau dari aspek kemampuan matematika saja, tetapi pada aspek lain yang mempengaruhi pemahaman siswa terhadap materi yang dipelajari, serta memilih dan menjadikan siswa yang memiliki kemampuan tinggi sebagai tutor sebaya dalam pembelajaran di kelas untuk membantu siswa yang memiliki kemampuan sedang dan rendah untuk mencapai semua lapisan pemahaman.

\section{DAFTAR PUSTAKA}

Afifah, D. S. N. (2006). Pemahaman siswa dalam memecahkan masalah matematika ditinjau dari perbedaan gaya kognitif. Universitas Negeri Surabaya.

Aisah, S. (2017). Profil lapisan pemahaman dan folding back siswa SMA dalam menyelesaikan soal logaritma ditinjau dari kemampuan matematika. UIN Sunan Ampel.

Astuti, S. P. (2015). Pengaruh kemampuan awal dan minat belajar. Jurnal Formatif, 5(1), 68-75. https://doi.org/dx.doi.org/10.30998/formatif.v5i1 .167.

Hakim, F. (2017). Analisis pemahaman mahasiswa PPS UNM berpandu teori pierekieren dalam menyelesaikan masalah pembuktian pada teori grup ditinjau dari gaya kognitif dan adversity quotient. Universitas Negeri Makassar. 
Hardiyanti, S., Lefrida, R., \& Amri, B. (2015). Penerapan pendekatan tutor sebaya untuk meningkatkan kemampuan siswa kelas VII SMP Negeri 1 Kasimbar dalam menyelesaikan pertidaksamaan linear satu variabel. AKSIOMA Jurnal Pendidikan Matematika, 4(2), 141-152. Retrieved from http://jurnal.untad.ac.id/jurnal/index.php/AKSIOMA/article/view/ $7752 / 6107$.

Komariyah, S., Septi, D., Afifah, N., \& Resbiantoro, G. (2018). Analisis pemahaman konsep dalam memecahkan masalah matematika ditinjau dari minat belajar siswa. SOSIOHUMANIORA: Jurnal Ilmiah Ilmu Sosial dan Humaniora, 4(1), 1-8. https://doi.org/dx.doi.org/10.30738/sosio.v4 i1.1477.

Mania, S., Raoda, W., Rasyid, M. R., \& Tayeb, T. (2019). Efektifitas penerapan model pembelajaran reciprocal teaching terhadap motivasi belajar dan pemahaman konsep matematika. Jurnal Pendidikan Dasar Islam, 6(1), 1425. https://doi.org/ doi.org/10.24252/10.24252/auladuna.v6i1a3.2019

Pratama, N. A. E. (2017). Perkembangan pemahamn matematis siswa sekolah dasar kelas $\mathrm{V}$ berdasarkan teori pirie-kieren pada topik pecahan. Jurnal $\begin{array}{llll}\text { Pendidkan Prodi Matematika, 19(1), 77-88. } & \end{array}$ https:/ / doi.org/dx.doi.org/10.17977/um009v26i12017p077.

Safitri, R. I., Mulyani, S., \& Ratu, N. (2018). Profil lapisan pemahaman konsep siswa SMP terkait garis tinggi segitiga, 6(2), 65-78. https://doi.org/dx.doi.org/10.25139/smj.v6i2.1141.

Sudijono, A. (2010). Pengantar statistika pendidikan. jakarta: PT Rajagrafindo Persada.

Suhardiman, Tayeb, T., \& Qadri, N. (2017). Perbandingan pemahaman konsep menggunakan metode pembelajaran scramble antara media interaktif courselab dan media microsoft powerpoint. Jurnal Pendidikan Fisika, 5(2), 99-105. https:// doi.org/doi.org/10.24252/jpf.v5i2a6.

Widyawati, Astuti, D., \& Ijudin, R. (2018). Kemampuan berpikir aljabar siswa dalam menyelesaikan soal cerita ditinjau berdasarkan kemampuan matematika. Jurnal Pendidikan dan Pembelajaran Khatulistiwa, 7(9), 1-8. Retrieved from http://jurnal.untan.ac.id/index.php/jpdpb/article/vie $\mathrm{w} / 28886 / 75676578650$. 